\title{
Preservation of Histology by Phenol-Based Fixative: Mini Review of Recent Findings
}

\author{
Preservación de la Histología Mediante un Fijador Basado en Fenol: \\ Una Mini Revisión de los Hallazgos Recientes
}

S. M. Niazur Rahman'; Tanbira Alam² \& Nazmun Nahar Alam ${ }^{3}$

RAHMAN, S. M. N.; ALAM, T. \& ALAM, N. N. Preservation of histology by phenol-based fixative: Mini review of recent findings. Int. J. Morphol., 39(1):50-56, 2021.

SUMMARY: In surgical and anatomical training, use of cadaver remains the most ideal technique. Standard formaldehyde solution preserves cadaveric tissues for an extended period comparing to the unfixed tissues. However, it fails to retain the natural texture, color, and biomechanical features. Phenol based soft embalming methods were developed to maintain these properties, while simultaneously decreasing the biohazard risk. Soft embalming techniques have made the bodies more 'lifelike' and wellfitted for training. Though phenol fixation displays rewarding morphological maintenance, we have scanty evidences on the histological preservation. This mini review primarily discussed the latest reports regarding the effect of phenol-based fixation on the tissue histology. Published literatures revealed phenol-based fixation displayed comparable histological preservation to that ofgold standard paraformaldehyde-based solution. It was concluded that phenol-based solution is an excellent fixative used to preserve tissues for microscopic analysis.

KEY WORDS: Phenol; Embalming solution; Soft embalming; Histological fixative; Microscopy.

\section{INTRODUCTION}

The cadaver is used as the most optimally simulated technique in surgical and anatomical training. Fresh unfixed tissue is presently the gold standard for these purposes. However, the temporal constraints of this material do not permit the use for longer periods (Lewis et al., 2012 Hines, \& Hiatt, 2012). Cadavers that have been donated to the institutes, necessarily require disinfection and preservation for future use (Reed et al., 2009). Formaldehyde (PFA), a substance frequently used in fixation, is able to maintain tissue by preventing degradation; though in the process, it alters the natural characteristics (Burkhart et al., 2010). Formalin, a solution contains $1-10 \%$ formaldehyde, remains the commonly used tissue fixative for cadaveric specimens (Thavarajah et al., 2012; Rao \& Ranganathan, 2012). Formaldehyde is low-cost and inhibits bacterial growth, however it has numerous linked health risks and hence classed as a carcinogen (International Agency for Research on Cancer, 2004; Brenner, 2014; Balta et al., 2015; O'Mahony, 2015). Newer embalming solutions, known as soft-embalming fixatives, have been created in attempts to avoid the decay of tissue while simulating the in vivo characteristics. Phenol is a substance that works like a preservative, as well as a disinfectant which is one of the main components of phenol-based embalming solution (Mayer, 2012). Phenol-based embalming fluid has proven to preserve the biomechanical features, color, and texture comparable to that of fresh tissue (Casier, 2012). Scientists are researching properties of this fixative to decide its potential use in anatomical education, surgical training and research applications. The outcomes from initial testing instances seem promising (Moore, 2010; Casier). Individual study stated that embalming with a phenol-based solution maintained the biomechanical features of the wrist joint comparable to that of fresh tissue (Casier). On a macroscopic level, soft-embalming solutions were found to have favorable applications; however, microscopically, not enough has been explored. Through our literature searching we found four studies on the histological characterization of phenol fixed tissues; digestive tract (Rahman, 2020), neural tissue (Tomalty, 2015), cerebral vasculature (Rockarts, 2016), and

\footnotetext{
${ }^{1}$ Department of Physiology, University of Toronto, Ontario, Canada.

${ }^{2}$ School of Kinesiology \& Health Studies, Queen's University, Ontario, Canada.

${ }^{3}$ Faculty of Medicine, AIMST University, Kedah, Malaysia.
} 
porcine muscle (Martyniuk et al., 2013). These studies provide the basis for expanding research histologically into other tissues.

Search of the literature: A systematic literature search was carried out using the Google Scholar, Ovid and Scopus databases. The search terms included: "histology", "phenol", "embalming" and "soft-embalming". In total, 47 literatures were refreshed. The search was limited to full text articles, in English, and with no date limit. Finally, 26 references were included in the manuscript and the histological findings were summarised from 4 reported literatures.

Embalming Solutions. Embalming fluids are composed of broad variety of reagents, containing the similar essential components: disinfectants, preservatives, surfactants, modifying agents, anticoagulants, colouring and masking agents. Each of these elements contributes in the overall functioning of the fluid (Brenner). Many embalming chemicals have multiple functions and therefore may fall into more than one of the aforementioned categories (Howat $\&$ Wilson, 2014). Table I. displays some basic information about most classical PFA and other common soft-embalming solution including phenol-based fixatives.

Soft Embalming. Fresh tissues and formaldehyde fixation, therefore, represent two extremes of anatomical samples, neither of which adequately meet the needs of researchers, educators, and students. Recent attention has been shifted to soft embalming. Soft-embalming is a term that covers a wide range of embalming methods, though different in their chemical composition, complexity, and cost, all function to integrate the benefits of fresh and formaldehyde-fixed tissues, while reducing their drawbacks. Though this technique is mostly in their infancy, but reported to provide more accurate representations of tissues, described to be grossly comparable to fresh cadaveric tissues regarding consistency, tissue coloration, and joint flexibility (Giger et al., 2008; Barton et al., 2009; Hunter et al., 2014). Moreover, it provides a great degree of tissue preservation and reduces the risk of infection (Barton et al.; Eisma et al., 2011). Though there are health hazards associated with the substances used in soft embalming solutions, they are considered safer than the carcinogenic elements used in formaldehyde-based solutions (Brenner). Frequently, soft embalming is being used in research and education since it provides more realistic tissue characteristics by maintaining color, flexibility, and texture.There are several soft embalming solutions used in research today. The focus of this paper, however, will remain on phenol-based embalming.

Phenol-Based Embalming Solution. This embalming solution typically contains alcohol, which acts as a disinfectant, glycol, a humectant, and phenol, acts as a preservative, germicide, and fungicide. Although phenol-based embalming is still a relatively novel technique, preliminary research has produced favorable results, showing potential in its ability to preserve in vivo characteristics of soft-tissues, including tissue flexibility, consistency, and coloration (Barton et al.).Researchers have focused on investigating the phenolbased embalming through explorations of the gross anatomy, histology, and biomechanical effects on various tissue types, including digestive tube, muscle, tendon, and cerebral vasculature (Casier; Martyniuk; Rockarts; Rahman). They have confirmed that phenol fixation preserves the gross as well as microscopic features, and therefore can be utilized for histologic studies (Martyniuk; Rahman). It is significant to note that the embalming solution used in these studies did not contain any formaldehyde, and yet still yielded exceptional levels of preservation both macroscopically and histologically. Most investigations into soft-embalming, including phenolbased solutions, have been focused on the gross anatomical effects, with few analyses available on their impact at the histologic level.

Table I. PFA and other commonly used soft-embalming fixatives.

\begin{tabular}{lllll}
\hline Organ/System & Tissue type & Fixative & Control & Staining \\
\hline Digestive & Rat & Phenol & $4 \%$ PFA & HE and MT \\
Neural & Porcine & Phenol & $4 \%$ PFA & HE and TB \\
Skeletal Muscle & Porcine & Phenol & $4 \%$ PFA & MT \\
Neural vasculature & Porcine & Phenol & $4 \%$ PFA & HE and MT \\
\hline
\end{tabular}

PFA: Paraformaldehyde, SSS: Saturated salt solution.

Table II. Summary of histological technique used in phenol-based fixation.

\begin{tabular}{lll}
\hline Embalming Solution & Method of Fixation & Contents \\
\hline PFA & Cross-linking & Paraformaldehyde, Sodium Hydroxide, Water. \\
Phenol-based & Coagulation/denaturation & $\begin{array}{l}\text { Phenol, ethanol, glycerin \& water. } \\
\text { Water, (mono-) ethylene-glycol, Ammonium }\end{array}$ \\
Thiel (1992) & Coagulation/denaturation & $\begin{array}{l}\text { nitrate, Sodium sulphite. } \\
\text { Sodium chloride, phenol, glycerine, isopropyl } \\
\text { SS }\end{array}$ \\
\hline
\end{tabular}

PFA: Paraformaldehyde, HE: Hematoxylin \& Eosin, MT: Masson's Trichrome, TB: Toluidine Blue 
Effects of Histological Preparation. The tissue preparation involves the following standard histological process: fixation, dehydration, clearing, infiltration, embedding, sectioning, and mounting. Histometric studies allow researchers to determine and compare a tissue's mechanical characteristic; however, the process for fixation and histological processing can alter their properties. It is known that fixation causes dimensional changes to tissue (Mescher, 2013). Shrinkage is caused by several factors. The fixation process involves the crosslinking proteins, which results in stiffening of the tissue (Wilke et al., 1996). Removal and replacement of fluid during the dehydration process, also results in decreased tissue volume. Additionally, embedding can results in some size reduction. Stains are applied to highlight various cellular elements in histological sections. The histological preparation applied to 4 different phenol fixed tissues are summarised in Table II.
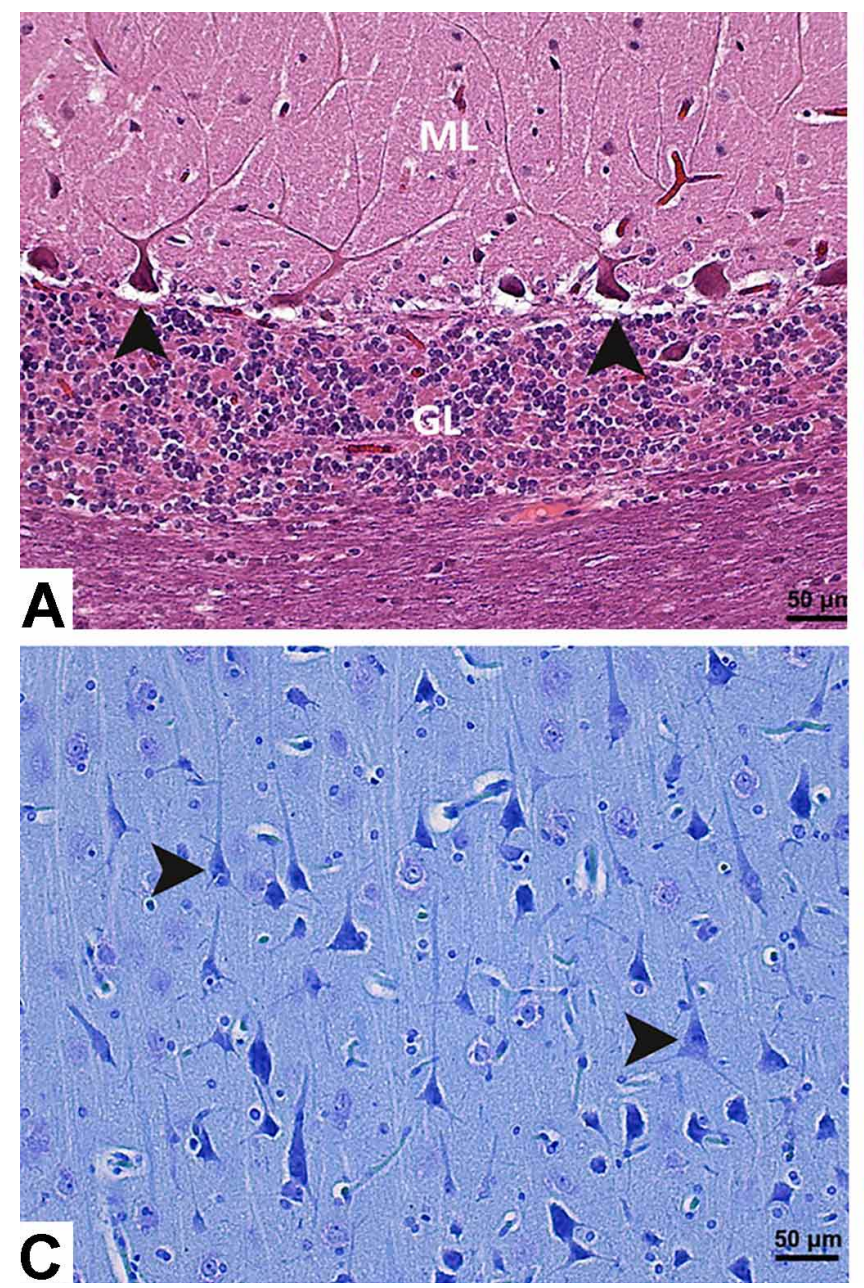

Fig. 1. H\&E and toluidine blue stained tissue sections of the cerebellar (A \& B) and cerebral (C \& D) cortex at 100X magnification. Image (A) and (C) show tissue fixed in formaldehyde, and images (B) and (D) display tissue embalmed in the phenol based solution. Separation artifact is notable in the cerebellar formaldehyde fixed tissue (A), yet not seen in the phenol embalmed tissue (B). Black arrows in the bottom panel indicate the large Pyramidal cells of the cerebral cortex. Cell somas of these large neuronal cells are clearly well preserved, including their prominent apical dendrites.
The PFA tissue sections presented in the literature (Eroschenko \& Di Fiore, 2008; Ross et al., 2009; Gartner \& Hiatt, 2014) displayed images having distinctive morphological preservation and staining patterns. As any variations from this standard are detectable histologically, PFA was taken as the control.

\section{Histological characterization of the tissues.}

Phenol-fixed Neural Tissue. Whole porcine brains were obtained and further dissected into cerebral and cerebellar blocks. Overall, phenol-embalmed tissue showed excellent preservation of the cerebral and cerebellar morphology compare to the PFA embalmed tissue (Tomalty et al., 2019). Detail analyses of the tissue revealed superior histological preservation by the phenol fixation in many aspects. At low magnification phenol-fixed tissues revealed excellent, almost
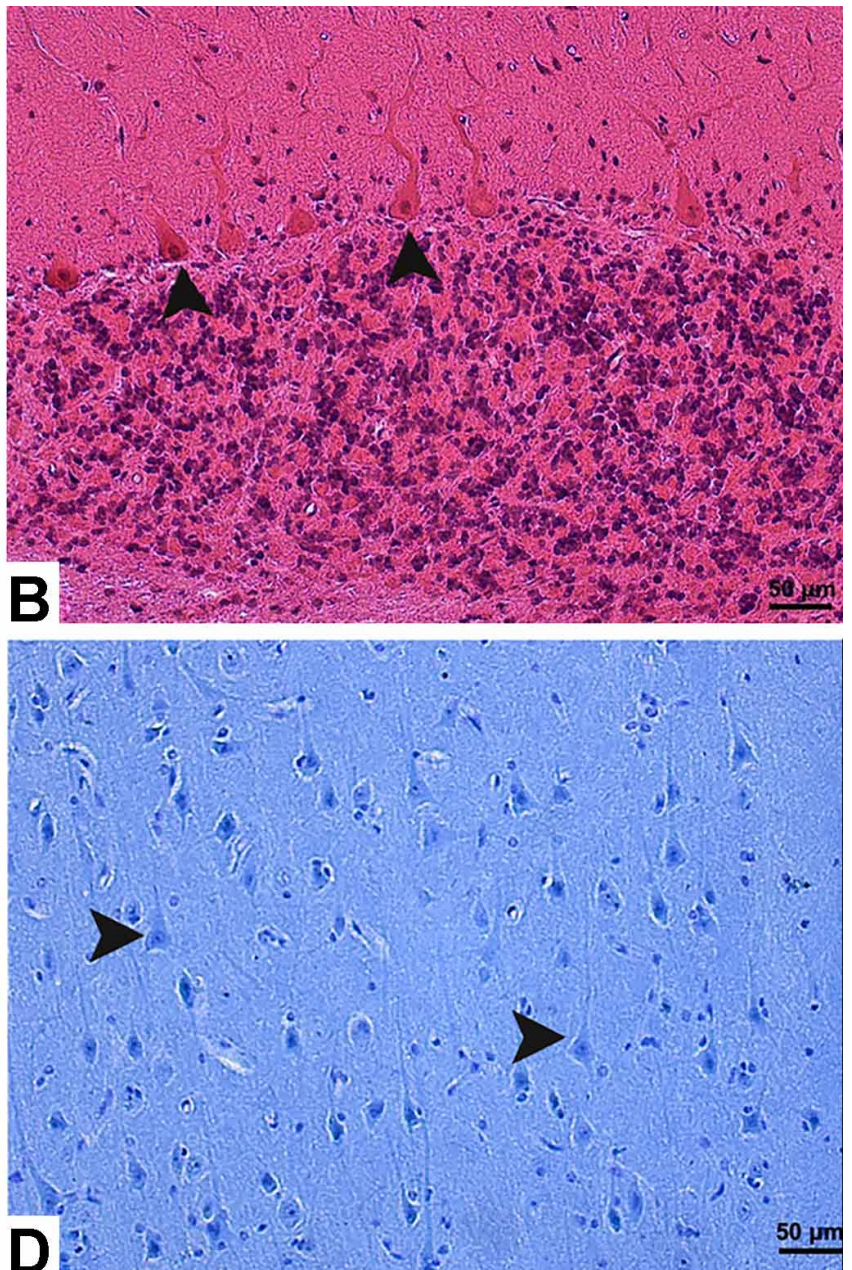
textbook quality of the cerebral and cerebellar morphology. The layers of both cortices, superficial meningeal layers and the associated neuronal cells were clearly distinguishable (Fig. 1). One observation of specific importance was the apparent decrease in separation artifact in the phenolembalmed tissue in comparison to the PFA sections.

Phenol-fixed Digestive Tissue. Different parts (esophagus, duodenum, ileum, and colon) of rat digestive tract were surgically harvested. The findings of this study (Rahman) reported impacts of phenol-fixation on digestive tract histology, which was visible using regular histological methods and stains. The key effects seen were changes in the staining pattern between the PFA and the phenol-fixed sections and the presence of separation artifacts in the wall of digestive tract. Regardless of these variances, the phenolfixation yielded good quality microscopic images (Fig. 2) that were comparable to those of the control. In many instances, the phenol-fixed images seemed to be superior to
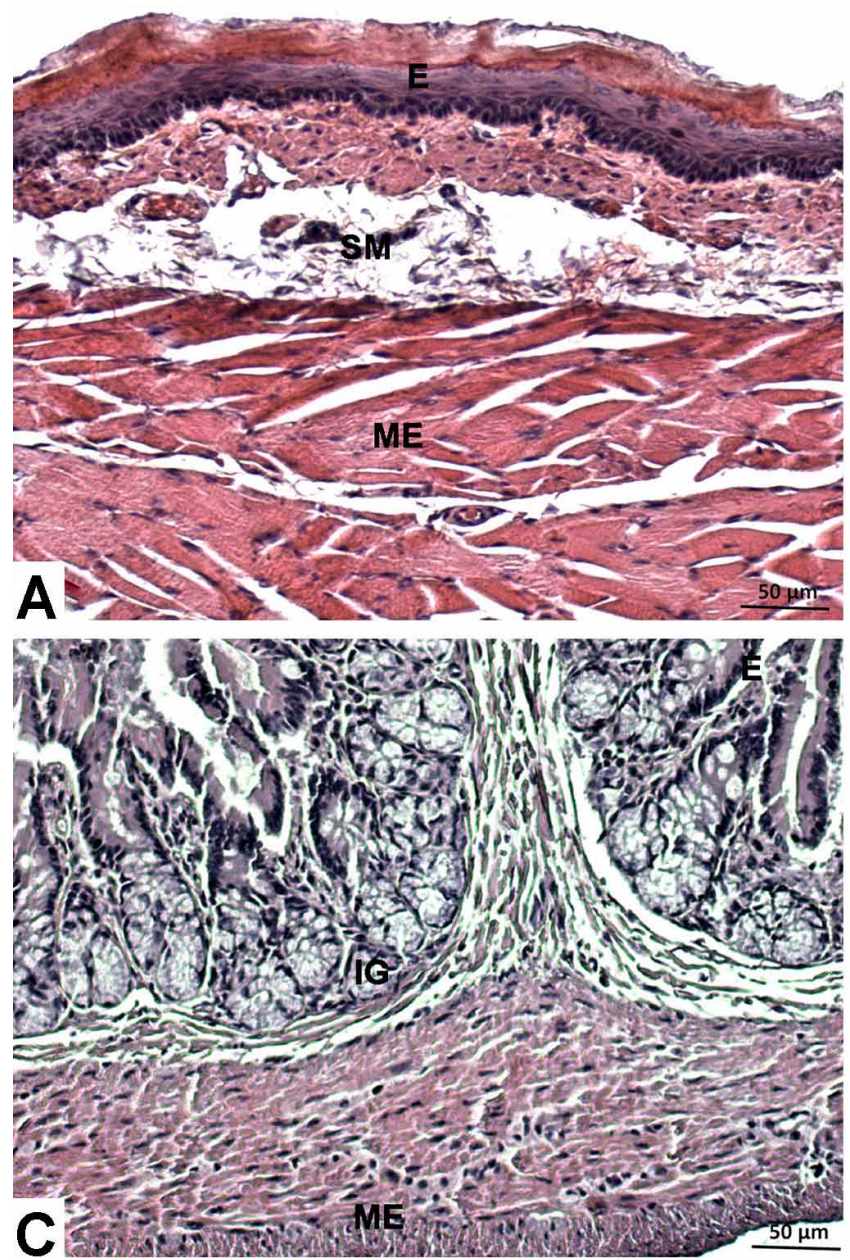

the PFA control; for example, the cellular clarity displayed better in phenol. The separation artifacts in the tissue layers were seen more in the phenol-fixed digestive tract sections. This indicates that the phenol-embalming produced some shrinkage of the tissue at the histological level. Although the staining disparities were evident in the H\&E sections, differences were less obvious between the Masson's Trichrome tissue sections. These staining differences included generalized intense eosinophilic staining of the phenol-embalmed H\&E-stained sections. Both the phenolembalmed and the PFA tissue were stained simultaneously, using the same staining solutions, and was performed in several batches; all displayed the same results. This supports that it is unlikely to have errors in the staining protocols causing the differences in staining results.

Phenol-fixed Skeletal Muscle. Deep flexor muscle and tendon were harvested from porcine forelimbs (Martyniuk). Samples were soft embalmed, histologically processed and
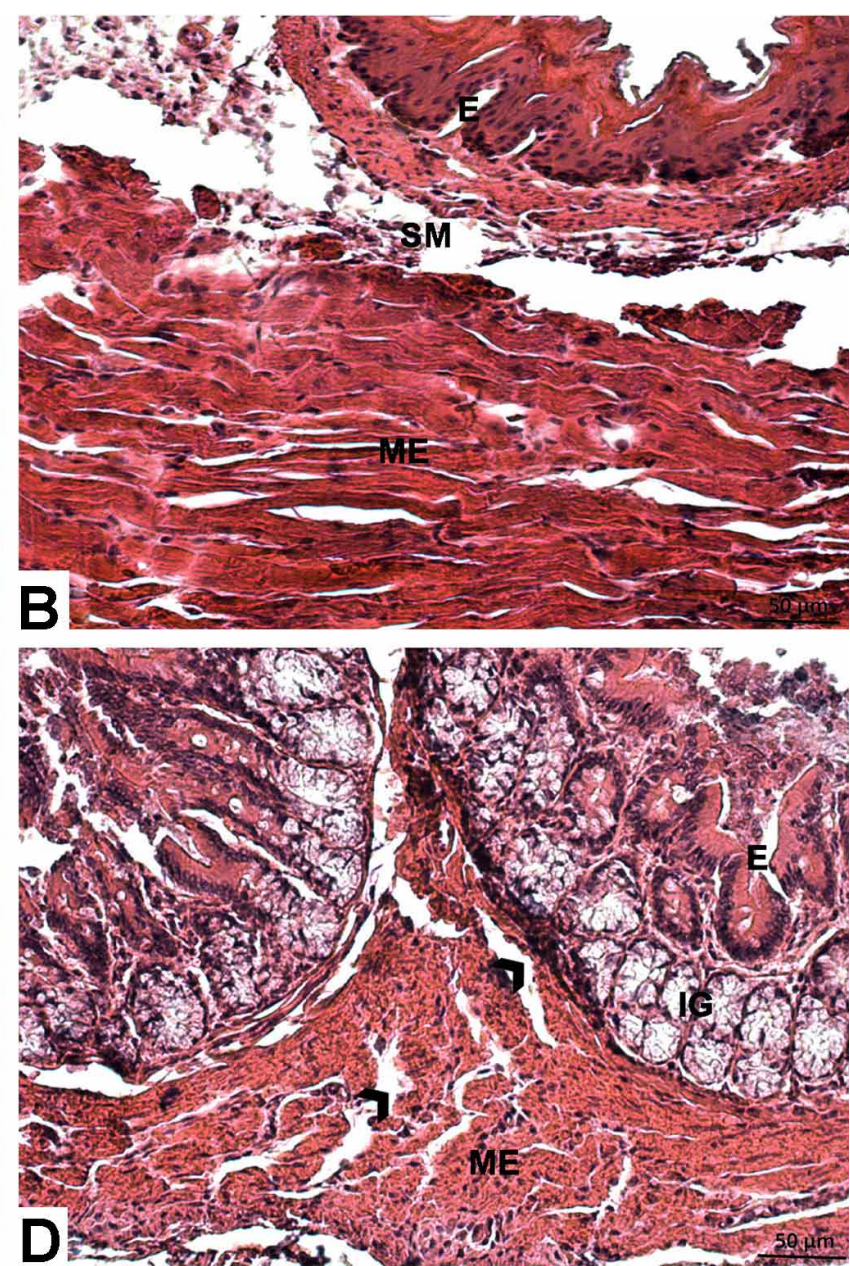

Fig. 2. H\&E stained tissue sections of the Esophagus (a \& b) and Colon (c \& d) at 10X magnification. Image (a) and (c) show tissue fixed in formaldehyde, and images (b) and (d) display tissue embalmed in the phenol-based solution. Phenol-embalmed sections show intense eosinophilic stain. In esophageal (a \& b) sections, thick muscularis externa (ME), loosely arranged submucosa (SM), muscularis mucosa (MM), stratified squamous epithelium (E) are preserved by both fixation methods. Separation artifact pointed by black arrows are notable in the phenol-fixed colon tissue (d). 
were visualized using Masson's trichrome staining. Microscopically, all samples displayed typical tendon structural characteristics. The staining of the tendons was almost entirely blue, as expected. All phenol embalmedmuscle samples exhibited typical colouring, but there were structuraldifferences (Fig. 3).

Phenol-fixed Neural Vasculature. Histological slides of phenol fixed porcine cerebral vascular tissue were prepared forlight microscopy using H\&E or MT stainingprotocol (Rockarts). The qualitative as well as quantitative changes of neural vasculature were analyzed for histometricchanges. The morphology of the tunica intima, including the endothelium and internal elastic lamina preserved well and was easily distinguishable. The tunica media was preserved well enough to demonstrate the thick Smooth muscle layers and their darkly staining nuclei. Any adventitia not destroyed during tissue processing preserved well. The adventitia was not always intact due to tissue processing, for this reason it was not included in the quantitative portion of this study. The phenol-fixed tissue was more pink in color, eosinophilic, compared to the control. The separation artifact in the phenolfixed tissue appeared to be smaller than that of the control tissue, suggesting that it preserves the vasculature more effectively than the $4 \%$ PFA control.The program ImageJ was used for the quantitative analysis by measuring arterial wall thickness.

This excluded the adventitia and surrounding tissue, as it was discontinuous and detached in numerous sections. The results from the $4 \%$ PFA and phenol-based fixative determined there was no significant difference. Therefore, phenol fixation proved to be a suitable alternative for histological analysis (Fig. 4).
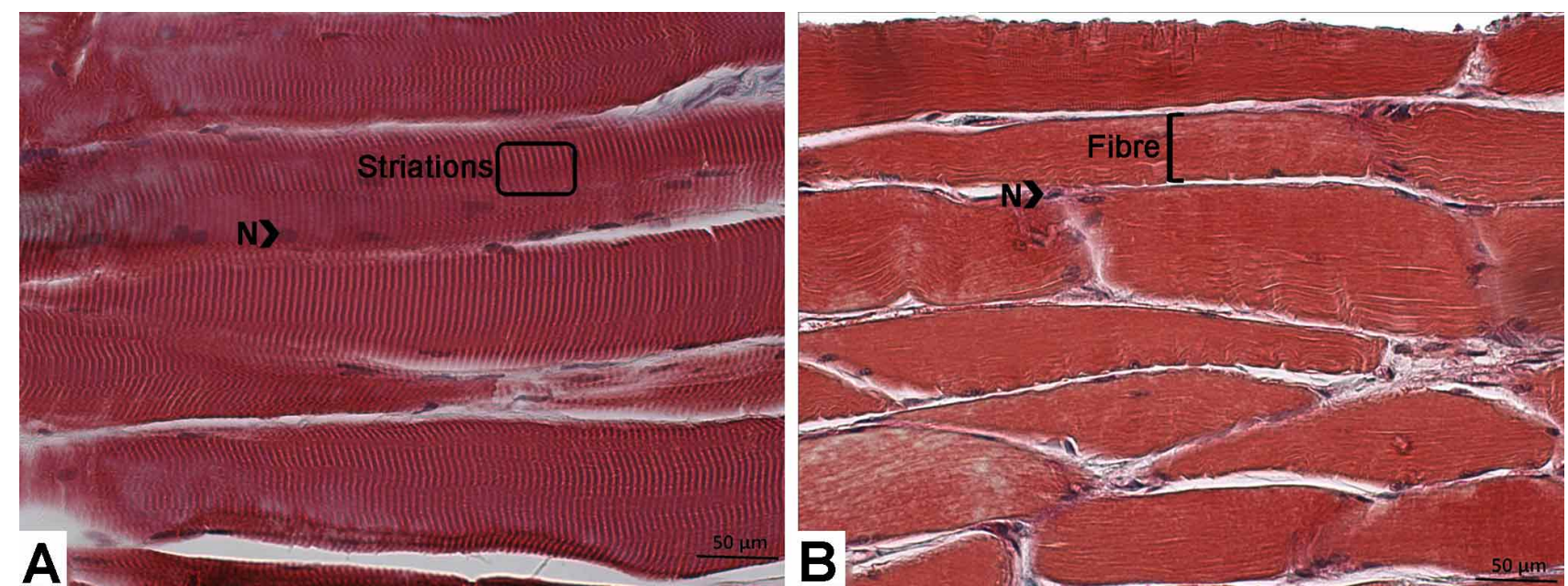

Fig. 3. H\&E stained skeletal muscle sections at 20X magnification. Image (a) shows tissue fixed in formaldehyde (PFA) and (b) displays tissue embalmed in the phenol-based solution. Black arrows indicate peripherally placed nucleus $(\mathrm{N})$ in both images. Striations are more obvious in the PFA section, while fibres are identifiable in both sides. 


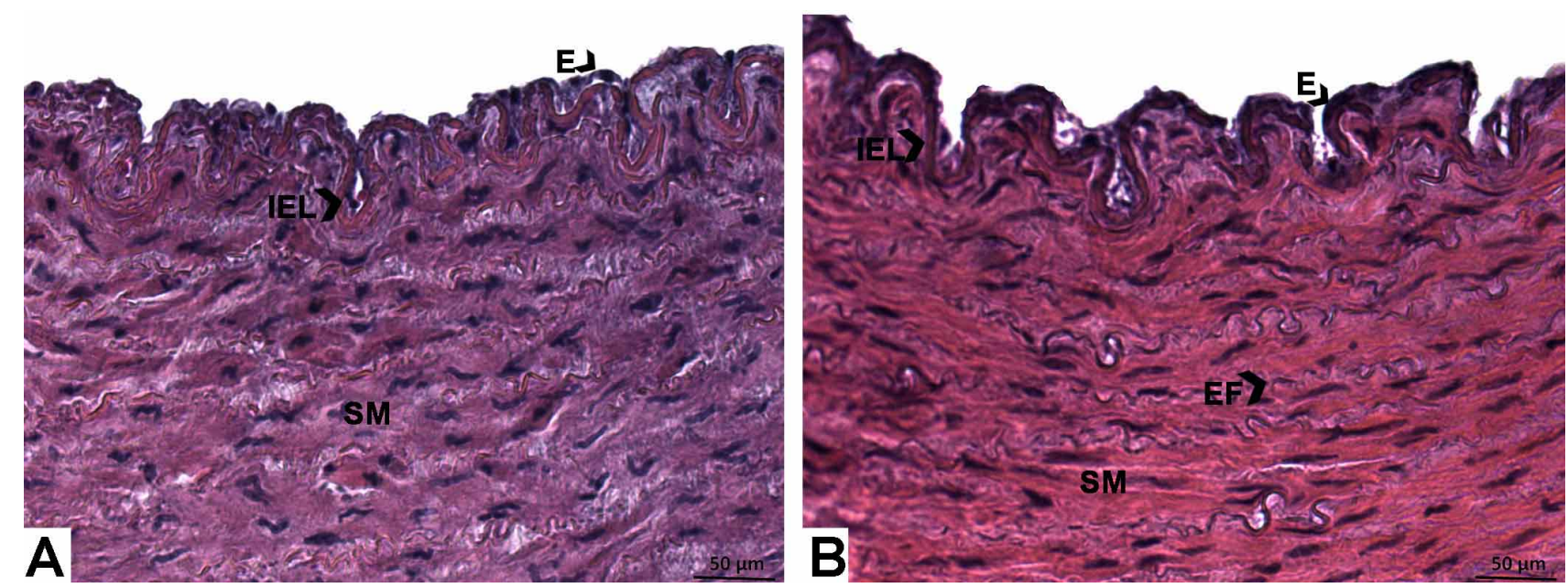

Fig. 4. H\&E stained carotid artery sections at 20X magnification. Image (a) shows tissue fixed in formaldehyde (PFA) and (b) displays tissue embalmed in the phenol-based solution. The morphological preservation of internal elastic lamina (Thiel, 1992) and endothelial cells (E) of the tunica intima. Smooth muscle cells (SM) and elastic fibres (EF) are well preserved in the tunica media.

Table III. Highlights of histological preservation by phenol-based fixation

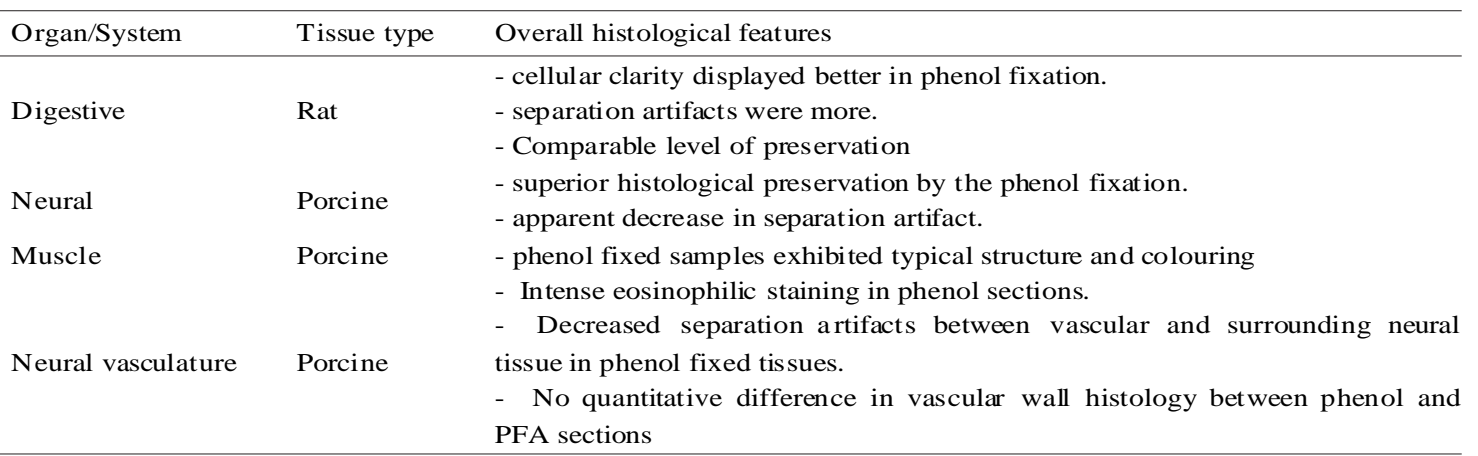

\section{CONCLUSION}

At large, this review summarised key insights of the effects of phenol-fixation on histological preservation. Softembalming procedures are important as they represent a potential substitute method of preservation by avoiding the drawbacks of formaldehyde-fixed as well as fresh tissues, while maintaining their benefits. Currently, research on soft embalming has largely been focused on the gross effects of the technique as a method for developing surgical models. The histological analysis of the phenol-fixed tissue supported further evidence that this method provides good overall structural preservation, analogous to those of the PFA control tissue.

RAHMAN, S. M. N.; ALAM, T. \& ALAM, N. N. Preservación de la histología mediante un fijador basado en fenol: Mini revisión de los hallazgos recientes. Int. J. Morphol., 39(1):50-56, 2021.
RESUMEN: En el entrenamiento quirúrgico y anatómico, el uso de cadáveres sigue siendo la técnica más ideal. La solución estándar de formaldehído conserva los tejidos cadavéricos durante un período prolongado en comparación con los tejidos no fijados. Sin embargo, no conserva la textura, el color y las características biomecánicas naturales. Se desarrollaron métodos de embalsamamiento blando a base de fenol para mantener estas propiedades y, al mismo tiempo, disminuir el riesgo biológico. Las técnicas de embalsamamiento suaves han hecho que los cuerpos sean más "realistas" y estén mejor preparados para la enseñanza. A pesar que la fijación de fenol muestra un buen mantenimiento morfológico, existe evidencia escasa sobre la preservación histológica. Esta mini revisión se refirió principalmente a los últimos informes sobre el efecto de la fijación en base de fenol en la histología del tejido. La literatura publicada reveló que la fijación a base de fenol mostró una preservación histológica comparable a la de la solución a base de paraformaldehído. Se concluyó que la solución a base de fenol es un excelente fijador utilizado para preservar tejidos para análisis microscópico.

PALABRAS CLAVE: Fenol; Solución de embalsamamiento; Embalsamamiento suave; Fijador histológico; Microscopía. 


\section{REFERENCES}

Balta, J. Y.; Cronin, M.; Cryan, J. F. \& O'Mahony, S. M. Human preservation techniques in anatomy: A 21st century medical education perspective. Clin. Anat., 28(6):725-34, 2015.

Barton, D. P. J.; Davies, D. C.; Mahadevan, V.; Dennis, L.; Adib, T.; Mudan, S.; Sohaib, A. \& Ellis, H. Dissection of soft-preserved cadavers in the training of gynaecological oncologists: Report of the first UK workshop. Gynecol. Oncol., 113(3):352-6, 2009.

Brenner, E. Human body preservation - old and new techniques. J. Anat., 224(3):316-44, 2014.

Burkhart, K. J.; Nowak, T. E.; Blum, J.; Kuhn, S.; Welker, M.; Sternstein, W.; Mueller, L. P. \& Rommens, P. M. Influence of formalin fixation on the biomechanical properties of human diaphyseal bone. Biomed. Tech. (Berl.), 55(6):361-5, 2010.

Casier, C. B. A Comparative Analysis of Radioulnar Deviation from FreshFrozen and Soft Embalmed Human Forearms; A Biomechanical Evaluation. M.Sc. Thesis. Kingston, Queen's University, 2012.

Eisma, R.; Mahendran, S.; Majumdar, S.; Smith, D. \& Soames, R. W. A comparison of Thiel and formalin embalmed cadavers for thyroid surgery training. Surgeon, 9(3):142-6, 2011.

Eroschenko, V. P. \& Di Fiore, M. S. H. Di Fiore's Atlas of Histology with Functional Correlations. $12^{\text {th }}$ ed. Philadelphia, Wolters Kluwer Health/ Lippincott Williams \& Wilkins, 2008.

Gartner, L. \& Hiatt, J. Color Atlas and Text of Histology. $6^{\text {th }}$ ed. Philadelphia, Wolters Kluwer Health/Lippincott Williams \& Wilkins, 2014.

Giger, U.; Frésard, I.; Häfliger, A.; Bergmann, M. \& Krähenbühl, L. Laparoscopic training on Thiel human cadavers: a model to teach advanced laparoscopic procedures. Surg. Endosc., 22(4):901-6, 2008.

Howat, W. J. \& Wilson, B. A. Tissue fixation and the effect of molecular fixatives on downstream staining procedures. Methods, 70(1):12-9, 2014.

Hunter, A.; Eisma, R. \& Lamb, C. Thiel embalming fluid--a new way to revive formalin-fixed cadaveric specimens. Clin. Anat., 27(6):853-5, 2014.

International Agency for Research on Cancer (IARC). IARC monographs on the evaluation of carcinogenic risks to humans. In: International Agency for Research on Cancer. Tobacco Smoke and Involuntary Smoking. Vol. 83. Lyon, IARC Press, 2004.

Lewis, C. E.; Peacock, W. J.; Tillou, A.; Hines, O. J. \& Hiatt, J. R. A novel cadaver-based educational program in general surgery training. J. Surg. Educ., 69(6):693-8, 2012.

Martyniuk, A. Histological Characterization of Soft-Embalmed Porcine Tendon and Muscle. M.Sc. Thesis. Kingston, Queen's University, 2013.

Mayer, R. G. Embalming: History, Theory, and Practice. $5^{\text {th }}$ ed. New York, Mcgraw-Hill Medical, 2012.

Mescher, A. L. Junqueira's Basic Histology: Text and Atlas. $15^{\text {th }}$ ed. New York, Mcgraw-Hill Medical, 2013.

Moore, C. W. A Comparison of Soft Embalming Methods for Colonoscopy Model Development. M.Sc. Thesis. Kingston, Queen's University, 2010.

Rahman, S. M. N. Preservation of Rat Digestive Tract by Phenol-based Embalming Solution. M.Sc. Thesis Anatomical Sciences. Kingston, Queen's University, 2020.

Reed, A. B.; Crafton, C.; Giglia, J. S. \& Hutto, J. D. Back to basics: use of fresh cadavers in vascular surgery training. Surgery, 146(4):757-62, 2009.

Rockarts, J. L. The Effect of a Soft-Embalming Solution on the Histological Structure of Porcine Cerebral Vasculature. M.Sc. Thesis. Kingston, Queen's University, 2016.

Ross, M. H.; Pawlina, W. \& Barnash, T. A. Atlas of Descriptive Histology. Sunderland, Sinauer Associates Incorporated, 2009.

Thavarajah, R.; Mudimbaimannar, V. K.; Elizabeth, J.; Rao, U. K. \& Ranganathan, K. Chemical and physical basics of routine formaldehyde fixation. J. Oral Maxillofac. Pathol., 16(3):400-5, 2012.
Thiel, W. The preservation of the whole corpse with natural color. Ann. Anat., 174(3):185-95, 1992

Tomalty, D. E. Gross Anatomical and Histological Characterization of SoftEmbalmed Porcine Neural Tissue. M.Sc. Thesis. Kingston, Queen's University, 2015.

Tomalty, D.; Pang, S. C. \& Ellis, R. E. Preservation of neural tissue with a formaldehyde-free phenol-based embalming protocol. Clin. Anat., 32(2):224-30, 2019

Wilke, H. J.; Krischak, S. \& Claes, L. E. Formalin fixation strongly influences biomechanical properties of the spine. J. Biomech., 29(12):1629-31, 1996.

Corresponding author:

S M Niazur Rahman

Department of Physiology

University of Toronto

1 King's College Circle

Medical Sciences Building

Room 3336

Toronto, M5S 1A8

Ontario

CANADA

\section{Email: niazur.rahman@mail.utoronto.ca niazur03@gmail.com}

ORCID ID: 0000-0002-0584-0792

Received: 22-08-2020

Accepted: 16-09-2020 